\title{
Cross-cultural adaptation of the Cyberchondria Severity Scale for Brazilian Portuguese
}

\author{
Tradução e adaptação transcultural da Cyberchondria Severity Scale para o \\ português brasileiro
}

Fernanda Gonçalves da Silva, ${ }^{1}$ Renata Andrade, ${ }^{2}$ Isabor Silva, ${ }^{2}$ Adriana Cardoso ${ }^{1}$

\begin{abstract}
Introduction: The internet has proven to be a valuable resource for self-care, allowing access to information and promoting interaction between professionals, caregivers, users of health care services and people interested in health information. However, recurring searches are often related to excessive health anxiety and a phenomenon known as cyberchondria can have impacts on physical and mental health. Within this background, a Cyberchondria Severity Scale has been developed to differentiate healthy and unhealthy behavior in internet searches for health information, based on the following criteria: compulsion, distress, excesses, and trust and distrust of health professionals.

Objective: To conduct cross-cultural adaptation of the Cyberchondria Severity Scale for Brazilian Portuguese, because of the lack of an appropriate instrument for Brazil.

Methods: This study was authorized by the original author of the scale. The process was divided into the following four steps: 1) initial translation, 2) back-translation, 3) development of a synthesized version, and 4) experimental application.

Results: Translation into Brazilian Portuguese required some idiomatic expressions to be adapted. In some cases, words were not literally translated from English into Portuguese. Only items $7,8,12,23$ and 27 were altered, as a means of both conforming to proper grammar conventions and achieving easy comprehension. The items were rewritten without loss of the original content.

Conclusion: This paper presents a translated version of the $\mathrm{Cy}$ berchondria Severity Scale that has been semantically adapted for the Brazilian population, providing a basis for future studies in this area, which should in turn contribute to improved understanding of the cyberchondria phenomenon in this population.
\end{abstract}

Keywords: Cyberchondria, scale, cross-cultural adaptation.

\section{Resumo}

Introdução: A internet tem se revelado um recurso valioso para o autocuidado, permitindo o acesso a informações e promovendo a interação entre profissionais, cuidadores, usuários de serviços de saúde e pessoas interessadas em informações sobre saúde. No entanto, pesquisas recorrentes na internet estão frequentemente relacionadas a ansiedade excessiva com saúde, e um fenômeno conhecido como cybercondria pode ocasionar danos à saúde física e mental do indivíduo. Nesse contexto, a Cyberchondria Severity Scale foi desenvolvida para diferenciar o comportamento saudável do não saudável no que diz respeito a pesquisas na internet sobre informações de saúde, com base nos seguintes critérios: compulsão, aflição, excessos e confiança/desconfiança nos profissionais de saúde.

Objetivo: Realizar a adaptação transcultural da Cyberchondria Severity Scale para o português brasileiro, em razão da falta de um instrumento adequado para uso no Brasil.

Métodos: Este estudo foi autorizado pelo autor original da escala. O processo foi dividido em quatro etapas: 1) tradução inicial, 2) retrotradução, 3) desenvolvimento de uma versão sintética, e 4) aplicação experimental.

Resultados: A adaptação para o português do Brasil exigiu algumas correções em expressões idiomáticas. Em alguns casos, as palavras não foram literalmente traduzidas do inglês para o português. Apenas os itens 7, 8, 12, 23 e 27 foram alterados, com o objetivo de seguir as normas gramaticais e favorecer a compreensão. Os itens foram reescritos sem que houvesse perda do conteúdo original.

Conclusões: Este trabalho apresenta uma versão traduzida da Cyberchondria Severity Scale que foi adaptada semanticamente para a população brasileira, proporcionando uma base para futuros estudos na área, o que deverá, por sua vez, contribuir para uma melhor compreensão do fenômeno cybercondria nessa população.

Descritores: Cybercondria, escala, adaptação transcultural.

\footnotetext{
${ }^{1}$ Instituto de Psiquiatria, Universidade Federal do Rio de Janeiro (UFRJ), Rio de Janeiro, RJ, Brazil. 2 Universidade Estácio de Sá, Nova Iguaçu, RJ, Brazil. Financial support: Conselho Nacional de Desenvolvimento Científico e Tecnológico (CNPq).

Submitted Jun 19 2015, accepted for publication Jan 14 2016. No conflicts of interest declared concerning the publication of this article.

Suggested citation: da Silva FG, Andrade R, Silva I, Cardoso A. Cross-cultural adaptation of the Cyberchondria Severity Scale for Brazilian Portuguese. Trends Psychiatry Psychother. 2016;38(2):90-95. http://dx.doi.org/10.1590/2237-6089-2015-0063
} 


\section{Introduction}

In recent decades, easy internet access has been one of the most important phenomena impacting the way that we live. Studies show that easy internet access has a great influence on people's habits and behaviors, including those relating to health issues. ${ }^{1,2}$ The internet has been revealed to be a valuable resource for selfcare, enabling access to information and promoting interaction between professionals, caregivers and health care service users ranging from chronic patients to people who are just interested in health information. ${ }^{3-6}$ The internet provides free access for everyone to a huge arsenal of medical information. Access to this content can be useful because it contributes to clarification of subjects. However, using this enormous repository of information to seek diagnoses may be distressful and result in increased levels of disease-related anxiety. ${ }^{7}$ Recurrent internet searches for medical diagnoses or symptoms, coupled with anxiety, usually influence people to believe that their symptoms are related to severe and rare diseases that are never benign. ${ }^{8}$

After investigating correlations between intolerance of uncertainty and web-search behaviors, Fergus s, $^{8,9}$ concluded that for some individuals these frequent searches for medical information on the internet are related to excessive health anxiety, a phenomenon that is now called cyberchondria. Researchers define cyberchondria as great health-related distress or concern, provoking excessive internet searches on the topic, which then lead to increased levels of anxiety and fear. This behavior, which is understood both as a healthrelated anxiety and as a manifestation of hypochondria, can have a serious impact on people's lives. ${ }^{10}$ This is a pathology that can be considered severe and debilitating. However, since research in the area is limited, the consequences of this behavior are poorly understood by both health professionals and the general public. ${ }^{11}$

Fergus $^{12}$ developed a revised version of the Cyberchondria Severity Scale (CSS) proposed by McElroy \& Shevlin ${ }^{10}$ to provide a means for measuring and distinguishing searches for health-related content from an inappropriate or compulsive behavior. This scale evaluates the following criteria: compulsion, distress, excesses, and trust and distrust of health care professionals in order to differentiate healthy from pathological behavior.

The CSS scale comprises 33 statements which respondents are requested to evaluate and respond to according to their own experience, using a 5-point frequency scale. Frequency response options range from 0 (never) to 4 (always). The instrument is presented in the form of a paper bearing the statements and a pencil to respond to them and can be self-administered or administered on an individual basis.

The scale was developed by McElroy \& Shevlin ${ }^{11}$ as a proposal to evaluate the severity of the behavior described (cyberchondria). Their study presented evaluations of 539 North American adults using this scale and also reported that the results were submitted to a factorial analysis and incremental and convergent validation and that internal consistency was assessed.

The confirmatory analysis revealed 5 factor groups: compulsion, anguish, excess, and medical trust and distrust, the last of which was the least consistent in the scale. The instrument demonstrated high internal consistency ( $\alpha=0.95$ ) and good simultaneous and convergent validity. The analysis also indicated significant correlations with health anxiety for the following factor groups: anguish and compulsion (0.80), excess and compulsion (0.63), excess and anguish (0.72), compulsion (0.43), anguish (0.52), excess (0.43), and medical trust and distrust (0.36). Follow-up studies with a 526-participant sample conducted an extension to the first study using a bifactor model of the CSS. ${ }^{10}$

A scale providing direct measurement of the cyberchondria phenomenon will not only be of use in a wide variety of future research projects, but will also contribute to development and validation of interventions for patients exhibiting this behavior.

The present study aims to conduct semantic adaptation of the CSS for Brazilian Portuguese. This adaptation will make it available for use in research involving Brazilian populations, thus enabling expansion of knowledge in this new and important area of study. ${ }^{11}$

\section{Method}

Semantic adaptation of the CSS for Brazilian Portuguese was authorized by the original author. The process was divided into the following four steps: 1) initial translation, 2) back-translation, 3) development of a synthesized version, and 4) experimental application. The first translation stage was conducted by two bilingual translators with expertise in mental health and psychometrics. The translators did not interact during the time they were working. In the second stage, these translations were translated from Brazilian Portuguese back into the scale's original language (English) by two bilingual mental health experts who had not taken part in the previous step.

The next step was development of a synthesized version. The scale then went through an evaluation of language clarity, relevance and theoretical dimensions. This work was conducted by a team of four mental 
health professionals with enough clinical experience to act as judges. This evaluation considered the scale to be adequate. The process then proceeded to experimental application of the approved version.

The experimental application aimed to identify any difficulties in understanding the items and to check whether the instrument fit the target population. This phase of the process involved 15 volunteers of both sexes. Ages ranged from 18 to 63 years and all had graduated from secondary education. The study complied with all existing ethical norms; participants agreed to take part and signed informed consent forms, which stated that participation was voluntary and that data would be treated holistically, thereby guaranteeing anonymity.

All participants completed the scale. We then analyzed possible omissions of answers on the forms received. The volunteers were asked how they had understood the meanings of the items they had answered and were then asked about any doubts regarding any of the items on the instrument. There were no difficulties in understanding the scale items. We therefore concluded that the participants correctly understood the meanings of the items that comprise the Brazilian version of the CSS.

The final Brazilian Portuguese version was then sent to the original author of the instrument, who approved it. Since there were no further proposals for amendment, the semantic adaptation of the CSS for Brazilian Portuguese was considered to be complete.

\section{Results}

Translation into Brazilian Portuguese required some idiomatic expressions to be adapted and, in some cases, words were not literally translated from English to Portuguese. This option was chosen as a means to preserve meanings without losing semantic content.
Only items 7, 8, 12, 23 and 27 were altered, as shown in Table 1. As a means of both conforming to proper grammar conventions and achieving easy comprehension, two items were rewritten without loss of the original content. In item 7 ("I am more easily annoyed or irritated after researching symptoms or perceived medical conditions online"), we chose to change "Eu fico mais ansioso ou irritado após pesquisar na Internet sobre os sintomas ou sobre os problemas de saúde percebidos" (literal back-translation: "I get more anxious or irritable after searching on the Internet about symptoms or health problems perceived") to "Eu fico mais facilmente ansioso ou irritado após pesquisar na Internet sobre sintomas ou problemas de saúde percebidos" (literal back-translation: "I get more easily anxious or irritable after searching on the Internet about symptoms or health problems perceived"). Item 27 ("Discussing online info about a perceived medical condition with my GP reassures me") was rewritten to "Discutir informações da Internet sobre um problema de saúde com meu médico me tranquiliza" ("Discussing with my doctor information I gathered on the Internet about health problems tranquilizes $m e^{\prime \prime}$.

For items 8 and 23, literal translations were changed to verbs and expressions to make them clearer to the target population. In item 8, "transmitir filmes" ("streaming movies") was changed to "assistir filmes" (literal backtranslation: "watch movies") to preserve the original meaning. Item 23, "indisposição no estômago" ("my stomach feels sick") was changed to "fico enjoado" (literal back-translation: "get sick"), to use an expression that is more common in the Brazilian Portuguese community.

Item 12 was adapted to fit Brazilian Portuguese grammar by inserting the pronoun "mim" as a verbal complement after the verb "percebi."

The items comprising the original scale were intended to be clear and objective. As a result, few adjustments were necessary after the translation performed by the experts (final version shown in Table 2). The same impression was reported by the participants of the experimental application.

Table 1 - Items changed

Original items
7. I am more easily annoyed or irritated after researching
symptoms or perceived medical conditions online.
8. Researching symptoms or perceived medical conditions online
interrupts my online leisure activities (e.g., streaming movies).

12. Researching symptoms or perceived medical conditions online interrupts my work (e.g., writing emails, working on word documents or spreadsheets).

Adapted items

7. Eu fico mais facilmente aborrecido ou irritado após pesquisar na Internet sobre os sintomas ou problemas de saúde percebidos.

8. Pesquisar na Internet sobre sintomas ou os possíveis problema de saúde que percebi interrompe minhas atividades online (como por exemplo assistir filmes).

12. Pesquisar na Internet sobre os sintomas ou problemas de saúde que percebo em mim interrompe meu trabalho (como escrever e-mails, trabalhar em documentos do Word ou planilhas).

23. I lose my appetite after researching symptoms or perceived medical conditions online, as my stomach feels sick.

23. Eu perco meu apetite depois de pesquisar na Internet sobre os sintomas ou os possíveis problemas de saúde que percebi, pois fico enjoado.

27. Discussing online info about a perceived medical condition

27. Discutir com meu médico as informações que pesquisei na with my GP reassures me.

Internet sobre problemas de saúde que percebi me tranquiliza. 
Table 2 - Final version of the Cyberchondria Severity Scale (CSS) in Brazilian Portuguese

\begin{tabular}{|c|c|c|c|c|c|}
\hline Itens & Nunca & Raramente & Algumas vezes & Frequentemente & Sempre \\
\hline $\begin{array}{l}\text { 1. Se eu notar alguma sensação corporal } \\
\text { estranha eu vou procurá-la na Internet. }\end{array}$ & (0) & (1) & (2) & (3) & (4) \\
\hline $\begin{array}{l}\text { 2. Pesquiso os mesmos sintomas na } \\
\text { Internet mais de uma vez. }\end{array}$ & (0) & (1) & (2) & (3) & (4) \\
\hline $\begin{array}{l}\text { 3. Pesquisar na Internet sobre os } \\
\text { sintomas ou os possíveis problemas de } \\
\text { saúde que percebi interrompe meu tempo } \\
\text { gasto no Facebook/Twitter/outras redes } \\
\text { sociais. }\end{array}$ & $(0)$ & (1) & (2) & (3) & (4) \\
\hline $\begin{array}{l}\text { 4. Pesquisar na Internet sobre os } \\
\text { sintomas ou os possíveis problemas de } \\
\text { saúde que percebi me leva a consultar } \\
\text { meu médico. }\end{array}$ & (0) & (1) & (2) & (3) & $(4)$ \\
\hline $\begin{array}{l}\text { 5. Eu tenho problemas para relaxar } \\
\text { depois de pesquisar na Internet sobre os } \\
\text { sintomas ou os possíveis problemas de } \\
\text { saúde que percebi. }\end{array}$ & (0) & (1) & (2) & (3) & (4) \\
\hline $\begin{array}{l}\text { 6. Pesquisar na Internet sobre os } \\
\text { sintomas ou os possíveis problemas de } \\
\text { saúde que percebi interrompe outras } \\
\text { pesquisas (por exemplo, meu trabalho/ } \\
\text { tarefa da faculdade/trabalho de casa). }\end{array}$ & (0) & (1) & (2) & (3) & $(4)$ \\
\hline $\begin{array}{l}\text { 7. Eu fico mais facilmente ansioso ou } \\
\text { irritado após pesquisar na Internet sobre } \\
\text { os sintomas ou problemas de saúde } \\
\text { percebidos. }\end{array}$ & $(0)$ & (1) & (2) & (3) & (4) \\
\hline $\begin{array}{l}\text { 8. Pesquisar na Internet sobre sintomas } \\
\text { ou os possíveis problema de saúde que } \\
\text { percebi interrompe minhas atividades } \\
\text { online (como por exemplo, assistir filmes). }\end{array}$ & (0) & (1) & (2) & (3) & (4) \\
\hline $\begin{array}{l}\text { 9. Levo a opinião do meu médico ou } \\
\text { profissional de saúde mais a sério do que } \\
\text { a minha pesquisa médica na Internet. }\end{array}$ & (0) & (1) & $(2)$ & (3) & (4) \\
\hline $\begin{array}{l}\text { 10. Eu entro em pânico quando leio na } \\
\text { Internet que um sintoma que tenho é } \\
\text { encontrado em algum problema de saúde } \\
\text { raro/grave. }\end{array}$ & (0) & (1) & $(2)$ & (3) & (4) \\
\hline $\begin{array}{l}\text { 11. Ao pesquisar sintomas ou problemas } \\
\text { de saúde na Internet, visito fóruns } \\
\text { onde os indivíduos diagnosticados ou } \\
\text { preocupados discutem suas condições } \\
\text { médicas, sintomas e experiências. }\end{array}$ & (0) & (1) & (2) & (3) & $(4)$ \\
\hline $\begin{array}{l}\text { 12. Pesquisar na Internet sobre os } \\
\text { sintomas ou problemas de saúde que } \\
\text { percebo em mim interrompe meu trabalho } \\
\text { (como escrever e-mails, trabalhar em } \\
\text { documentos do Word ou planilhas). }\end{array}$ & $(0)$ & (1) & (2) & (3) & (4) \\
\hline $\begin{array}{l}\text { 13. Eu leio diferentes páginas da Internet } \\
\text { sobre o mesmo problema de saúde que } \\
\text { percebi. }\end{array}$ & $(0)$ & (1) & $(2)$ & (3) & $(4)$ \\
\hline $\begin{array}{l}\text { 14. Pesquisar na Internet sobre os } \\
\text { sintomas ou os possíveis problemas de } \\
\text { saúde que percebi interrompe minhas } \\
\text { atividades sociais presenciais (reduz o } \\
\text { tempo gasto com amigos/família). }\end{array}$ & (0) & (1) & (2) & (3) & $(4)$ \\
\hline $\begin{array}{l}\text { 15. Discuto minhas descobertas } \\
\text { médicas na Internet com o meu médico/ } \\
\text { profissional de saúde. }\end{array}$ & (0) & $(1)$ & $(2)$ & (3) & (4) \\
\hline $\begin{array}{l}\text { 16. Sugiro ao meu médico/profissional } \\
\text { de saúde que posso precisar de um } \\
\text { procedimento de diagnóstico sobre o } \\
\text { qual eu li na Internet (por exemplo, uma } \\
\text { biópsia / um exame de sangue específico. }\end{array}$ & (0) & (1) & (2) & (3) & (4) \\
\hline
\end{tabular}


17. Pesquisar na Internet sobre os sintomas ou os possíveis problemas de saúde que percebi me distrai da leitura de notícias/esportes/entretenimento on-line.

18. Eu leio as mesmas páginas da Internet sobre condições médicas percebidas em mais de uma ocasião.

19. Quando eu procuro um sintoma online, eu sinto que o ranking dos resultados de busca da Internet reflete o quão comum é uma doença, com os problemas de saúde mais prováveis aparecendo no início da página de resultados?

20. Eu penso estar bem até ler sobre um problema de saúde sério na Internet?

21. Eu visito fontes confiáveis (por exemplo, http://bvsms.saude.gov.br/) ao pesquisar os sintomas ou os possíveis problemas de saúde que percebi.

22. Eu me sinto mais ansioso ou estressado após pesquisar online sobre sintomas ou condições médicas percebidas.

23. Eu perco meu apetite depois de pesquisar na Internet sobre os sintomas ou os possíveis problemas de saúde que percebi, pois fico enjoado.

24. Pesquisar na Internet sobre os sintomas ou os possíveis problemas de saúde que percebi interrompe ou torna mais lenta a minha comunicação on-line (por exemplo, mensagens instantâneas, Skype).

25. Pesquisar na Internet sobre os sintomas ou os possíveis problemas de saúde que percebi interrompe minhas atividades de trabalho fora da Internet.

26. Pesquisar na Internet os sintomas ou os possíveis problemas de saúde que percebi me faz consultar outras especialidades médicas.

27. Discutir informações da Internet sobre um problema de saúde com meu médico me tranquiliza.

28. Eu confio mais no diagnóstico do meu médico/profissional de saúde do que em meu autodiagnóstico na Internet.

29. Eu acho difícil parar de me preocupar com os sintomas ou os possíveis problemas de saúde que percebi e sobre os quais eu pesquisei na Internet.

30. Ao pesquisar sintomas ou problemas de saúde na Internet eu visito tanto os sites confiáveis quanto fóruns de usuários.

31. Eu tenho problemas para dormir depois de pesquisar na Internet sobre os sintomas ou os possíveis problemas de saúde que percebi, pois os resultados ficam se repetindo na minha mente.

32. Eu me pego pensando: "Eu não teria ido ao médico se eu não tivesse lido sobre esse sintoma/problema de saúde na Internet".

33. Quando o meu médico/profissional de saúde descarta minha pesquisa médica na Internet, eu paro de me preocupar com isso.
(0)

(1)

(2)

(3)

(4)

(1)

(2)

(3)

(1)

(2)

(1)

(2)

(1)

(1)

(1)

(1)

(2)

(0)

(1)

(2)

(0)

(1)

(2)

(1)

(2)

(0)

(1)

(2)

(0)

(1)

(2)

(0)

(1)

(2)

(0)

(1)

(2) 


\section{Discussion}

Psychometric instruments translated with consideration for cultural determinants enable new research to be conducted and expand the range of instruments available to professionals working in clinical settings. This is why the cross-cultural adaptation process for the CSS described in this paper was conducted, as a contribution to professionals working in this area of study.

In the first stage, translations were performed incorporating the necessary adjustments to ensure that the original meanings of the items would be preserved. As a result, understanding of the instrument was guaranteed by completing a primary and necessary step of evaluation of semantic equivalence.

The cross-cultural adaptation process included a series of analyses of verbal comprehension by experts and volunteers. They reported that the items were clear and objective and that the wording of the items contributed to easy understanding of the instrument.

The research participants (volunteers and experts) did not make any suggestions for structural changes of items. There was therefore no need for further adjustments, so the translated version maintained the same components of the original version.

This study aimed to translate and semantically adapt the CSS for the Brazilian population, providing a basis for future validation work and measurement of the instrument's reliability with this population, while also contributing to increasing understanding of the subject.

\section{Conclusion}

Searching for health information and diagnoses on the internet is becoming more common. Differentiating what constitutes a normal search from compulsive behavior has been a major challenge for researchers and practitioners dealing with patients exhibiting these behaviors.

We note that cyberchondria is a recent phenomenon whose impacts are still unknown, but searching for health information by the general outsider public is a behavior that can have consequences beyond anxiety, because of errors of evaluation that lead subjects to always identify themselves with the most serious cases. One can also raise the hypothesis that these habits could impact on and delay professional help because people may consider themselves capable of conducting their own diagnoses based on search results. Additionally, this behavior may promote self-medication, considering that this type of information can also be shown explicitly on internet sites. This paper presents a translated version of the CSS, semantically adapted for the Brazilian population, providing a basis for future studies in this area, which should in turn contribute to improved understanding of the cyberchondria phenomenon in this population.

\section{References}

1. Starcevic V, Berle D. Cyberchondria: towards a better understanding of excessive health-related Internet use. Expert Rev Neurother. 2013;13:205-13.

2. Henderson EM, Keogh E, Eccleston C. Why go online when you have pain? A qualitative analysis of teenagers' use of the Internet for pain management advice. Child Care Health Dev. 2014;40:572-9.

3. White RW, Horvitz E. Cyberchondria: studies of the escalation of medical concerns in web search. ACM Trans Manag Inf Syst. 2009;27:23.

4. Stone J, Sharpe M. Internet resources for psychiatry and neuropsychiatry. J Neurol Neurosurg Psychiatry. 2003;74:10-2.

5. Lewis T. Seeking health information on the Internet: lifestyle choice or bad attack of cyberchondria? Media Cult Soc. 2006;28:521-39.

6. Muse K, McManus F, Leung C, Meghreblian B, Williams JM. Cyberchondriasis: fact or fiction? A preliminary examination of the relationship between health anxiety and searching for health information on the Internet. ] Anxiety Disord. 2012;26:189-96.

7. White RW, Horvitz E. Captions and biases in diagnostic search ACM Trans Web. 2013;7:23.

8. Fergus TA. Cyberchondria and intolerance of uncertainty: examining when Individuals experience health anxiety in response to Internet searches for medical information. Cyberpsychol Behav Soc Netw. 2013;16:735-9.

9. Harding KJ, Skritskaya N, Doherty E, Fallon BA. Advances in understanding illness anxiety. Curr Psychiatry Rep. 2008;10:3117.

10. Norr AM, Allan NP, Boffa JW, Raines AM, Schmidt NB. Validation of the Cyberchondria Severity Scale (CSS): replication and extension with bifactor modeling. J Anxiety Disord. 2015;31:5864

11. McElroy E, Shevlin M. The development and initial validation of the cyberchondria severity scale (CSS). J Anxiety Disord. 2014;28:259-65.

12. Fergus TA. The Cyberchondria Severity Scale (CSS): an examination of structure and relations with health anxiety in a community sample. J Anxiety Disord. 2014;28:504-10.

\section{Correspondence:}

Fernanda Gonçalves da Silva

Instituto de Psiquiatria, Universidade Federal do Rio de Janeiro, Campus Praia Vermelha

Av. Venceslau Brás, 71, fundos, $2^{\circ}$ andar, sala do Comitê de Ética em Pesquisa

22290-140 - Botafogo, RJ - Brazil

Tel.: + 55 (21) 2446.7085

E-mail: fernandagoncalves.fgs@gmail.com 